\title{
Management of erosive tooth wear
}

\author{
Manejo do desgaste dentário erosivo
}

Thalya Fernada Horsth Maltarollo

São Leopoldo Mandic, Brasil

E-mail: thalyamaltarollo@gmail.com

Letícia de Oliveira Domingues

Centro Universitário das Faculdades Metropolitanas Unidas, Brasil

E-mail: ledomingues2@hotmail.com

Irineu Gregnanin Pedron

Universidade Brasil, Brasil

E-mail: igpedron@alumni.usp.br

George Brooks Hughes Júnior

Universidade Brasil, Brasil

E-mail: ggbrooksgeorge@gmail.com

Keisy dos Santos Pais

Universidade Brasil, Brasil

E-mail:hellokeisy22@gmail.com

Gabriel Patrick Medeiros Cavalcante de Araújo

Universidade Brasil, Brasil

E-mail: gabspatrick@gmail.com

Caleb Shitsuka

Universidade Brasil, Brasil

E-mail:cashitsuka@gmail.com

\begin{abstract}
Erosive tooth wear is an oral health problem that worries clinicians and researchers worldwide. The aim of this study is to describe, through a literature review, the erosive tooth wear management. This problem is a challenge for dental surgeons, especially when it reaches more advanced stages, which can cause loss of dental and aesthetic function, as well as generate hypersensitivity to the patient. To prevent the progression of this problem focusing into preventive measures, such as guidelines for feeding and oral hygiene, the dental surgeon must perform early diagnosis to minimize erosive tooth wear damage.
\end{abstract}

Keywords: Tooth wear; Tooth erosion; Non-carious lesions.

\section{Resumo}

O desgaste dentário erosivo é um problema de saúde bucal que preocupa clínicos e pesquisadores no mundo. O objetivo da pesquisa é descrever através de uma revisão de literatura o manejo do desgaste dentário erosivo. Este problema é um desafio para os cirurgiões-dentistas, especialmente quando atinge estágios mais avançados, que podem causar perda da função dentária e estética, além de gerar hipersensibilidade ao paciente. Para evitar a progressão desse problema, com foco em medidas preventivas, como orientações alimentares e de higiene bucal, o cirurgião-dentista deve realizar o diagnóstico precoce para minimizar os danos do desgaste dentário erosivo.

Palavras-chave: Desgaste dos dentes; Erosão dentária; Lesões não-cariosas.

\section{Introduction}

Dental erosion is a complex and multifactorial oral health problem that affects the hard tissues of teeth ${ }^{1}$. This dental wear affects especially children and adolescents with recent changes in lifestyle, mainly because of the high consumption of acidic foods and beverages ${ }^{2,3}$. 
The erosion is caused by an irreversible chemical process of mineral and superficial structure losses of the teeth due to acid aggression without bacteria involvement ${ }^{4,5}$ and erosive tooth wear is defined as the accelerated los of dental hard tissue through the combined effect of erosion and mechanical wear (abrasion and attrition) on the tooth surface ${ }^{6}$.

The clinical diagnosis of erosive lesions is based on anatomical and morphological alterations of the tooth and can be observed with the loss of mineral tissue on the surface of the teeth ${ }^{4,7}$. The acids responsible for the dental surfaces aggression may have an intrinsic or extrinsic origin ${ }^{4,8}$.

Because of high prevalence, dental erosion has become a concern for patients and dental surgeons, especially when it reaches advanced stages causing loss of function and esthetics of the teeth, moreover hypersensitivity ${ }^{9,10}$. In these cases, treatment becomes a challenge for health professionals ${ }^{2}$. To avoid the worsening of this problem, dental surgeons can use preventative measures, such as use of fluoride, dietary guidelines and oral hygiene guidelines ${ }^{3,11,12}$.

In this context, it is important that the dental surgeon has an understanding and a knowledge of the erosive tooth wear process with an early diagnosis to avoid its progression ${ }^{9}$.

\section{Methodology}

In this literature review, 33 articles were selected from the following databases: Pubmed, Lilacs, Scielo, Google Scholar, from 1991 to 2021, in Portuguese and English.

\section{Literature Review}

Erosive tooth wear has a multifactorial character and it is caused by acids that reach the oral cavity and may be of intrinsic or extrinsic origin ${ }^{4,13,14}$ and the combined effect of mechanical wear (abrasion and attrition) ${ }^{6}$. Our body provides an important form of natural protection present in the mouth that is the salivary fluid ${ }^{15,16}$. The salivary fluid has an important property of neutralizing the acids in the oral environment, known as saliva buffer capacity ${ }^{13}$.

Due to the complexity of the onset of this problem, it is important to consider all factors that may develop it. The following factors may be mentioned: behavioral (type of diet, occupation, drug use, hygiene habits, eating habits), biological (tooth anatomy, biofilm, movements of mouth soft tissue) and chemicals (calcium and phosphate concentrations, saliva buffer capacity, salivary $\mathrm{pH})^{13}$. The habit of ingesting citrus foods and drinks enhances erosive wear once it is known that citric acid promotes a chemical effect called a chelate effect. This happen because citric acid binds to calcium ions present in the dental structure and "steals" these teeth minerals ${ }^{17,18}$. The increased intake of acidic beverages such as soft drinks and artificial juices causes great concern seeing that they are often stimulated and linked to advertisements as being "healthy"19,20.

After the correct diagnosis, it is necessary to indicate an adequate treatment plan, which often involves the control of the sensitivity and aesthetic correction, as they can be some of the patient's main complaints, but mainly the removal of the etiological factor to reach a definitive solution for the problem ${ }^{11,12}$.

After identifying the etiology of the lesions, it is important to prevent new lesions and to control the progression of existing lesions. To avoid the worsening of this problem, dental surgeons may use preventive measures such as therapeutic use of fluorides and dietary guidance ${ }^{12}$. The use of fluoride is indicated for patients with disequilibrium in the demineralizationremineralization process of the tooth that occurs in dental erosion. There are several methods of use such as: fluoride gel, fluorine varnish, fluoridated dentifrices and mouthwashes that should be used in an individualized indication and only until the balance of this des-re process occurs ${ }^{11,21-23}$.

Because dental erosion wear presents few clinical signs and no painful symptomatology, the early diagnosis of it is underestimated. Erosive lesions are difficult to diagnose, as they are often easily confused with other types of dental lesions 
such as non-carious lesions ${ }^{7,9,24}$. In cases of hypersensitivity the use of fluorides and desensitizers should be evaluated together with the guidelines related to diet and oral hygiene ${ }^{12,25}$.

Currently several indexes are used to diagnose and classify dental erosion. The BEWE index, is indicated for both epidemiological studies and private practice, since it is simple and easy. Besides, it indicates the severity of the dental erosion and it also proposes a treatment ${ }^{12}$. Olley et al.,2014 ${ }^{26}$ validated the BEWE sextant cumulative score. This score appears to provide a simple method to alert clinicians to the erosive tooth wear process.

The restoration of erosive lesions should be considered only in severe cases, when loss of aesthetics and function occurs. Composite resins, glass ionomer and even crowns can be used for the patient ${ }^{2,4}$ but it is important to highlight that the disease will continue to progress if there is no control of the etiological factor ${ }^{12}$.

Early diagnosis is essential for damage to be minimized, as the progression of the problem leads to the appearance of new lesions along with enamel dissolution and dentine exposure, with the possibility of complete destruction of the tooth crown and pulp involvement ${ }^{27}$. Patients and / or caregivers rarely recognize the initial signs. Thus, it is up to the professionals to seek the characteristics of the erosive lesion on clean, dry and well-lit surfaces 9 .

This dental health problem is becoming a concern and reality mainly for dental surgeons, who in recent years try to understand more about this process through research, for improvements in diagnosis, prevention and treatment of erosive tooth wear ${ }^{8,12,28-30}$.

It is important that Dental education, in person or remotely, must transmit these guidelines so that they are applied in professional practice ${ }^{31-33}$.

\section{Conclusion}

The dental surgeon must have an understand of erosive tooth wear in order to perform the early diagnosis of erosive lesions, in view of the extremely importance to reach a better prognosis in the treatment of the oral health problem.

\section{References}

1. World Health Organization, ICD - International Statistical Classification of Diseases and Related Health Problems, $10^{\text {th }}$ Revision; 2010.

2. Bartlett DW. The role of erosion in tooth wear: aetiology, prevention and management. Int Dent J. 2005; 55(4 Suppl 1): $277-84$.

3. Salas MM, Nascimento GG, Huysmans MC, Demarco FF. Estimated prevalence of erosive tooth wear in permanent teeth of children and adolescents: an epidemiological systematic review and meta-regression analysis. J Dent. 2015; 43(1): 42-50.

4. Lussi A, Jaeggi T. Erosion--diagnosis and risk factors. Clin Oral Investig. 2008; 12 Suppl 1: S5-13.

5. Carvalho TS, Baumann T, Lussi A. Does erosion progress differently on teeth already presenting clinical signs of erosive tooth wear than on sound teeth? An in vitro pilot trial. BMC Oral Health. 2016; 17(1): 14.

6. Huysmans MC, Chew HP, Elwood RP. Clinical studies of dental erosion and erosive wear. Caries Res. 2011; 45 Suppl 1:60-8.

7. Shitsuka C, Mendes FM, Corrêa MS, Leite MF. Exploring some aspects associated with dentine hypersensitivity in children. Scientific World Journal. 2015; 2015:764905.

8. Schlueter N, Jaeggi T, Lussi A. Is dental erosion really a problem?. Adv Dent Res. 2012; 24(2): 68-71.

9. Jaeggi T., Lussi A. Prevalence, incidence and distribution of erosion. Monogr Oral Sci. 2014; 25: 55-73.

10. Ganss C, Lussi A. Diagnosis of erosive tooth wear. Monogr Oral Sci. 2014; 25: 22-31.

11. Bartlett D, Ganss C, Lussi A. Basic Erosive Wear Examination (BEWE): a new scoring system for scientific and clinical needs. Clin Oral Invest. 2008 ; 12 Suppl 1: S65-8.

12. Lussi A, Hellwig E. Risk assessment and preventive measures. Monogr Oral Sci. 2006; 20: 190-9.

13. Lussi A., Jaeggi T. Erosion--diagnosis and risk factors. Clin Oral Investig. 2008; 12 Suppl 1: S5-13. 
14. Alvarez LL, Fabruccini FA, Alves LS, Alvarez VR, Maltz M. Erosive Tooth Wear among 12-Year-Old Schoolchildren: A Population-Based CrossSectional Study in Montevideo, Uruguay. Caries Res. 2015; 49(3): 216-25.

15. Dodds MW, Johnson DA, Yeh CK. Health benefits of saliva: a review. J Dent. 2005; 33(3): 223-33.

16. Buzalaf MA, Hannas AR, Kato MT. Saliva and dental erosion. J Appl Oral Sci. 2012; 20(5): 493-502.

17. Waterhouse PJ, Auad SM, Nunn JH, Steen IN, Moynihan PJ. Diet and dental erosion in young people in south-east Brazil. Int J Paediatr Dent. 2008; 18(5): $353-60$.

18. Li H, Zou Y, Ding G. Dietary factors associated with dental erosion: a meta-analysis. PLoS One. 2012; 7(8): e42626.

19. Järvinen VK, Rytömaa II, Heinonen OP. Risk factors in dental erosion. J Dent Res. 1991; 70(6): 942-7.

20. Featherstone JD, Lussi A. Understanding the chemistry of dental erosion. Monogr Oral Sci. 2006; 20: 66-76.

21. Corrêa MSNP, Corrêa FNP, Corrêa JPNP, Murakami C, Mendes FM. Prevalence and associated factors of dental erosion in children and adolescents of a private dental practice. Int J Paediatr Dent. 2011; 21(6): 451-8.

22. Kreulen CM, Van 't Spijker A, Rodriguez JM, Bronkhorst EM, Creugers NH, Bartlett DW. Systematic review of the prevalence of tooth wear in children and adolescents. Caries Res. 2010; 44(2): 151-9.

23. Lussi A, Schlueter N, Rakhmatullina E, Ganss C. Dental erosion - an overview with emphasis on chemical and histopathological aspects. Caries Res. 2011; 45 Suppl 1: 2-12.

24. Zero DT, Lussi A. Erosion--chemical and biological factors of importance to the dental practitioner. Int Dent J. 2005; 55(4 Suppl 1): 285-90.

25. Risemberg RIS, Silva AKRO da, Pedron IG, Shitsuka C, Maltarollo TH. Conhecimento dos responsáveis sobre o dentifrício fluoretado e fluorose. EACAD [Internet]. $1^{\circ}$ de junho de 2021 [citado $4^{\circ}$ de setembro de 2021];2(2):e022226. Disponível em: https://eacademica.org/eacademica/article/view/26

26. Olley RC, Wilson R, Bartlett D, Moazzez R. Validation of the Basic Erosive Wear Examination. Caries Res. 2014; 48(1):51-6.

27. Huysmans MC, Young A, Ganss C. The role of fluoride in erosion therapy. Monogr Oral Sci. 2014; 25: 230-43.

28. O’Toole S, Mistry M, Mutahar M, Moazzez R, Bartlett D. Sequence of stannous and sodium fluoride solutions to prevent enamel erosion. J Dent. 2015; 43(12): $1498-503$

29. Pinheiro CF, Melo MPF, Silva RR da, Pedron IG, Shitsuka C. Lesões não cariosas: revisão de literatura. EACAD [Internet]. $10^{\circ}$ de junho de 2021 [citado $4^{\circ}$ de setembro de 2021];2(2):e042227. Disponível em: https://eacademica.org/eacademica/article/view/27

30. Maltarollo TH, Pedron IG, Medeiros JMF, Kubo H, Martins JL, Shitsuka C. A erosão dentária é um problema!. RSD [Internet]. $3^{\circ}$ de março de 2020 [citado $4^{\circ}$ de setembro de 2021];9(3):e168932723. Disponível em: https://rsdjournal.org/index.php/rsd/article/view/2723

31. Valente GSC, Moraes Érica B de, Sanchez MCO, Souza DF de, Pacheco MCMD. O ensino remoto frente às exigências do contexto de pandemia: Reflexões sobre a prática docente . RSD [Internet]. 9 $9^{\circ}$ de setembro de 2020 [citado $4^{\circ}$ de setembro de 2021];9(9):e843998153. Disponível em: https://rsdjournal.org/index.php/rsd/article/view/8153

32. Santo E do E. Ensinar e aprender na Educação a Distância: um estudo exploratório na perspectiva das práticas tutoriais. RSD [Internet]. $8^{\circ}$ de dezembro de 2016 [citado $4^{\circ}$ de setembro de 2021];3(2):92-114. Disponível em: https://rsdjournal.org/index.php/rsd/article/view/16

33. Rocha SSD, Joye CR, Moreira MM. A Educação a Distância na era digital: tipologia, variações, uso e possibilidades da educação online. RSD [Internet]. $9^{\circ}$ de abril de 2020 [citado $4^{\circ}$ de setembro de 2021];9(6):e10963390. Disponível em: https://rsdjournal.org/index.php/rsd/article/view/3390 